\title{
Geological Evaluation and Lateral Facies Variability of gazelle Field: Implication on Volumetric Analysis
}

\author{
Abimbola Adewole Durogbitan (PhD) \\ Independent Principal Consultant
}

\begin{abstract}
The main objective of this study is to determine and confirm the economic viability of the Gazelle field as reported in series technical evaluation reports received from previous workers, with primary focus of developing this field as the first phase of a greater block wide strategy. A fully independent volumetric analysis was undertaken in order to ascertain the GIIP within the Gazelle structure. This involved replicating an established previous workers inputs and also re-running Monte Carlo probabilistic cases using @Risk Software. Some of uncertainties were unravelled from their inputs. The uncertainties identified from the volumetric analysis ranges from depth conversion, depth to contact, reservoir thickness, and reservoir extent (sand distributions). These uncertainties have great impact on the GRV which in turn have great impact on the over-estimated GIIP presented by the previous worker. All the geological uncertainties were quality checked $(Q C)$ in order to get correct inputs guided by oil and gas global standard. These uncertainties were unravelled by re-construction of correlation panel across the wells.
\end{abstract}

Geologically, the Gazelle Field comprises a combination stratigraphic/structural trap encompassing Cenomanian-Turonian and Senonian slope channel reservoir sequences deposited within shelf and slope setting. The field is characterised by lateral facies variability as observed from the well correlation panel; which is one of the major geological uncertainty encountered in this field.

\section{INTRODUCTION}

This study is to determine and confirm the economic viability of the Gazelle Field as reported in series technical evaluation reports received from previous workers, with primary focus of developing this field as the first phase of a greater block wide strategy.

The Gazelle field is located in Cote d'lvoire, Block CI-202, 40 $\mathrm{km}^{2}$ SE of Abidjan with water depth of 40-50m (Figure 1)

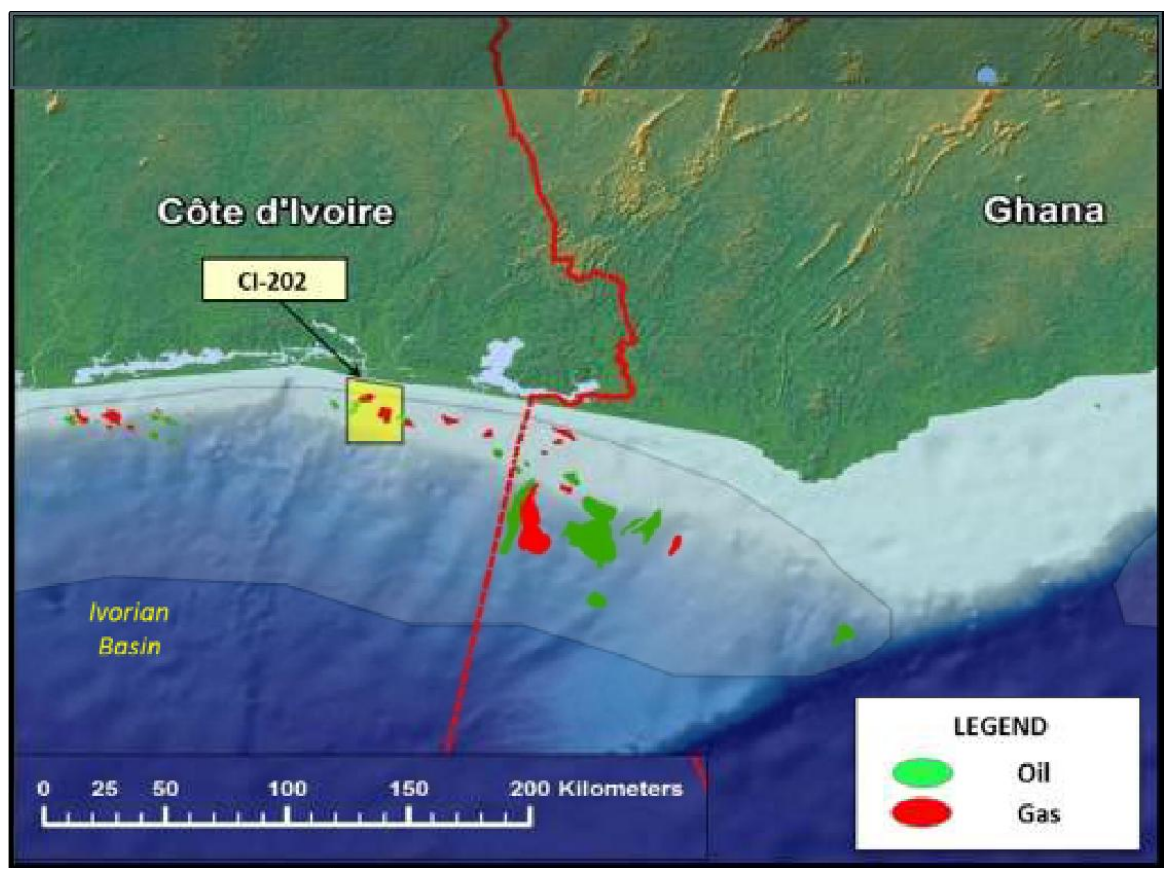

Figure1. Block CI-202 Regional Location (from FDP 2012) 


\section{Available Data}

The available data include top structural surfaces of the reservoir units which was based on the interpretation/mapping from 3D Seismic cube via a petrel project; raw well log data, CPI, well locations, some well tops, petro physical reports and some relevant field study reports.

\section{Regional GeOlogy}

The study area (shallow water) is situated on the southern-rifted margin of West Africa that was formerly joined to South America in the Early Cretaceous. Onshore of the study area is the Lagunes fault system that defines the northern edge of Albian faulting and basically the shelf-margin fill. Moving seaward there is segmented faulting creating a series of seaward tilted fault blocks with some antithetic faulting towards the coast. The younger overlying Cenomanian to Senonian section drapes over and fills in the topography related to faulting and erosion that occurred in the Late Albian to Early Cenomanian. From the seismic sections, both strike and dip view show significant channelling, slumping and erosion of the shelf margin during apparent Low stands of relativesea level in the Upper Cretaceous. This process would suggest sand stone reservoirs could be located in these areas of sediment bypassing and may define and tested reservoir targets in down dip slope, toe of slope and basinal settings.

The reservoir intervals that contain hydrocarbons are from Albian to Maastrichtian in geologic age, Early to Late Cretaceous (fig. 2). The lithologies commonly found are interbedded sandstones with siltstones and shales. The Albian section is dominated by siltstone, shales, and thin limestone marls. Sandstone reservoir rocks are limited in occurrence. The reservoir quality however improves in the Cenomanian to Senonian package in the nearshoreareas. The quality of reservoirs tested further offshore, may not be as good, ingeneral, as the more proximal deposits. The dominant trap style present in the study area is considered to bestratigraphic or combination stratigraphic/structural traps. Draping is mostevident in the Cenomanian to Lower Senonian sedimentary fill. The sandstones occur as disconnected bodies that seem to fill structural lows and onlap adjoiningAlbian topography.Based on seismic data there are suggestions of incised valley fill, slope deposits on clinoforms and base of slope sediment gravity flow, turbidite sandstone channels that are transitional to siltstones and shales (Rialto, FDP 2012).

\section{REgional STRATigraphy}

Pre-rift stratigraphy includes Devonian and Permo-Carboniferous sandstones as encountered in wells drilled offshore Ghana. Rifting commenced in the Early Aptian (or Barremian) forming confined basins which were filled with a thick sequence ofsyn-rift Apto-Albian lacustrine claystones and turbidite to delta sandstones. Sandsupply diminished during the Late Albian, when more open marine conditions become established across the margin (Morrison et al 1999). The Albian restricted lacustrine shales and the Upper Cretaceous marine claystones, in particular basinal Turonian shales, form excellent source rocks. The Lower Albian sediments are the oldest penetrated offshore Cote d'Ivoire and the Middle to Upper Albian reservoirs are productive at Foxtrot Gas Field and the Espoir and Lion oil fields. Post-rift, Late Cretaceous delta and submarine fan systems developed across the Abidjan Margin and these are the reservoirs for the CI-202 discoveries as well as the Panthere (gas), Belier (oil), B-3X (gas/condensate) and Lion (oil) fields. A radical change in depositional conditions took place from neritic during the Cenomanian-Santonian to much deeper and partially restricted marine during / after the Early Campanian following a major reactivation of the transform fault system. Submarine channel systems were reactivated during this time. From the Latest Cretaceous through the Tertiary, the sedimentary sections largely show a basin infilling character (fig. 2). 


\section{STRATIGRAPHY}

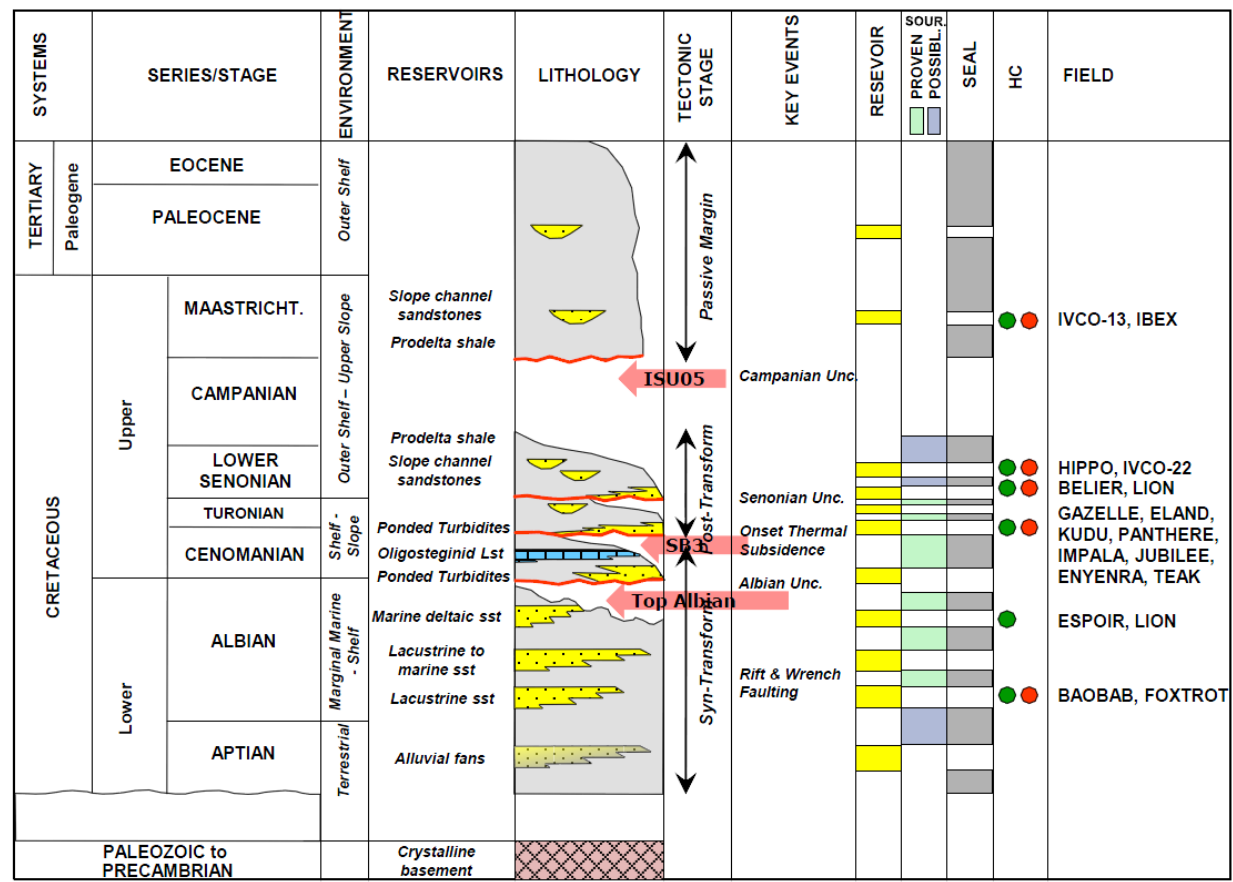

Figure2. Regional Stratigraphy chart (from Morrison et al 1999).

\section{EXPloRATION AND APPRAISAl History OF BLOCK CI-202}

Block CI-202 is located offshore Cote d'lvoire in West Africa and is operated by C\&L Natural Resources (C\&LNR), a 100\% owned subsidiary of Rialto Energy Limited, with an $85 \%$ working interest. PETROCI holds the remaining $15 \%$ with $5 \%$ payinginterest. The block is located about $40 \mathrm{~km}$ southeast of the commercial capital of Abidjan, is $675 \mathrm{~km}^{2}$ and forms part of the Ivorian Basin which extends west wards into Liberia and eastwards into Ghana. Water depths range from 0m (shoreline) to1000m (Rialto, FDP 2012).

Drilling in Block CI-202 started in 1972. Seven Block CI-202 wells can be classed as discovery wells. The planned drilling for Block CI-202 includes two campaigns; 3 wells starting in Q1 2012, and 3 wells starting in Q4 2012. These wells meet Block CI-202 PSC exploration drilling commitments and provide development wells for the Gazelle Field development outlined in this Field Development Plan (FDP).In addition to the development of the Gazelle Field a near term objective is to determine the optimal appraisal strategy for the existing discoveries within the block and for the exploration of further prospects. All the discoveries are either unapprised or under-appraised oil and gas discoveries including, Hippo-1, IVCO-22(Bubale), IVCO-18 (Impala) and IVCO-13 \& 25 (Addax). The exploration portfolio currently contains 14 prospects with un-risked gross mean resources of 500MMbbland 1.8Tcf.A significant advantage to cost-effective development of Block CI-202 is the close proximity of the existing discoveries and adjacent prospects, which will allow tieback to nearby facilities rather than each discovery requiring standalone development. An additional benefit of this concept is that any smaller hydrocarbon pools which would not ordinarily warrant development can be added and be readily brought into production (Rialto, FDP 2012).

\section{GAZELLe Field}

C\&LNR's primary focus is the development of the Gazelle Field as the first phase of a greater block wide strategy. Rialto have reported that there is sufficient confidence given the number of wells drilled to-date, tested and overall field evaluation to commit to a field development. The Gazelle Field is a multilayer oil and gas/condensate accumulation, located approximately $40 \mathrm{~km}$ south-east of Abidjan. Water depth at this location is 45-50m. The discovery well was drilled by Esso in 1977. Gazelle has historically been considered an oil development project, as there was no economic way to 
monetize the gas reserves. However, the Cote d'Ivoire gas market has now matured, mainly for onshore power generation, making gas export economic. This allows utilisation of a national resource rather than the alternative of flaring. Below are the Gazelle Field summary histories to date(Rialto, FDP 2012).

\subsection{Gazelle Field Summary History}

\section{Discovery well:}

- $\quad$ IVCO-12 drilled in 1977

- No reservoir in primary objective- Albian horizon

- Encountered Upper Cenomanian sand drape over the Albian High

- Tested sands at a maximum combined flow rate; 3,418bopd, 315bcd and 42.1MMsfgd

\section{Appraised by:}

- IVCO14 (1977)- encountered additional reservoir in the Upper Cenomanian, 2,288bopd and 12.1MMscfgd

- $\quad$ Esso 3D Seismic survey (1978)

- IVCO-21 (1980)- appraised Upper Cenomanian sands and encountered additional reservoirs in the Lower Cenomanian, high pressure gas reservoir, 10MMscfgd

- Gazelle-1 (1988)-appraised Cenomanian 36.5MMscfgd and 7.5MMscfgd

- $\quad$ UMIC Gazelle 3D Seismic Survey (1995)

- Gazelle-2 (1997)- appraised the Lower Cenomanian at 32.5MMscfgd

\section{Development well}

- Gazelle-P3 ST1 \& ST2- (2012)

Press release by Rialtoin July 2012, confirmed that Gazelle-P3 ST2 well achieved a maximum flow rate of $19.5 \mathrm{MMscfd}$ gas and an unstablised rate of 760 bopd from separate sand with the Upper Cenomanian (UC-1) reservoir

In summary, the Gazelle-P3 ST1 directional well ("ST1 well") penetrated the UC-1 reservoirs 800metres from the existing IVCO-14 discovery well and also appraised the Gazelle primary gasreservoir (LC-2). The well also successfully penetrated a down-dip portion of the high impact (750 $\mathrm{BCF}$ ) Condor prospect. The ST2 well was then drilled to further appraise and test the UC-1 reservoirs closer to the IVCO-14 well. The ST1 and ST2 wells are located on Block CI-202, with ST1 and ST2 wells drilled to total depths of $3685 \mathrm{mRT}$ and $2979 \mathrm{mRT}$ respectively.

Both ST1 and ST2 wells have achieved a number of exploration, appraisal and development objectives, as outlined below:

1. Significant reduction of the geological risk of the greater Condor prospect $(750 \mathrm{BCF}$ mean prospective resource) due to the thickening of the interval up-dip to the North where reservoir quality is predicted to improve. The ST1 well drilled a portion of the Condor Prospect (LC-5) and discovered gas in a thick, low permeability reservoir. A Condor appraisal well is one of several high impact candidates earmarked for drilling in 2013.

2. Extension of the vertical extent of the gas bearing LC-2 reservoir by $200 \mathrm{~m}$ TVD as well as establishing probable communication of the LC-2 reservoir with penetrations in the up-dip Gazelle-2 well (tested at $32.5 \mathrm{mmscfd}$ ) and on the southern side of the fault in the IVCO-21 well.

3. Appraising and testing the extent and quality of the UC-1 oil and gas reservoirs (UC-1A, UC-1B and UC-1C sands) down dip of the IVCO-14 well and establishing continuity of the gross sand interval between the IVCO-14 well and ST2. 
4. Obtaining necessary oil and gas samples from the UC-1 and LC-2 reservoirs to facilitate development and confirm compositions.

5. The penetration by the ST1 well of a new, high quality Lower Cenomanian $75 \mathrm{~m}$ gross sand interval which provides an additional exploration target for the Block.

\subsection{Geological Analysis}

\subsection{Reservoir units}

For the purpose of this technical evaluation, three units were evaluated for hydrocarbon in place. These are Units LC1, LC2 and UC1C. Wells that encountered these units were summarised in table below with their reservoir interval.

Table1. Gazelle -Lc1, Lc2 \&Uc1c Reservoir Interval Surmmary

\begin{tabular}{|c|c|c|c|c|c|c|c|c|c|c|c|c|c|}
\hline \multirow{3}{*}{$\begin{array}{c}\text { Reservoir } \\
\text { interval }\end{array}$} & \multirow{3}{*}{$\begin{array}{c}\text { Primary } \\
\text { Phase } \\
\end{array}$} & \multicolumn{12}{|c|}{ Wells } \\
\hline & & \multicolumn{3}{|c|}{ IVCO-21 } & \multicolumn{3}{|c|}{ IVCO-14 } & \multicolumn{3}{|c|}{ Gazelle-2 } & \multicolumn{3}{|c|}{ Gazelle P3ST2 } \\
\hline & & Top & Base & Intv. $m$ & Top & Base & Intv. $m$ & Top & Base & Intv. $m$ & Top & Base & Intv. $m$ \\
\hline LC1 & Gas & 2598 & 2610 & 13 & & & & & & & & & \\
\hline LC2 & Gas & 2469 & 2474 & 7 & & & & 2455 & 2469 & 14 & & & \\
\hline UC1C & Gas & & & & 2409 & 2416 & 7 & & & & 2368 & 2410 & 10 \\
\hline
\end{tabular}

\section{Volumetric Calculations}

The principal objective of this evaluation was to confirm the original GIIP presented by the previous worker in their technical evaluation reports. A fully independent volumetric analysis was undertaken in order to ascertain the GIIP within the Gazelle structure. This involved replicating their inputs and also running my own Monte Carlo probabilistic cases using @Risk Software. A summary table of which well tested the reservoir units were summarised in table 1.

\section{Geological ASSUMptions And UnCERTAinties}

The uncertainties identified from the volumetric analysis by previous worker ranges from depth conversion, depth to contact, reservoir thickness, and reservoir extent (Sand distributions). These uncertainties have great impact on the GRV which in turn have great impact on the over-estimated GIIP presented by Rialto. All the geological uncertainties were quality checked (QC) in order to get correct inputs guided by oil and gas global standard. All these geological uncertainties were summarised in (Table 2).

These uncertainties were also unravelled by re-construction of correlation panel across the wells(IVCO-21, IVCO-12, GAZELLE-2 \& IVCO-14)(figure3). From the analysis given previous worker, they proposed that the LC1 and LC2 sand pinch out at the edge of the top structure maps. However, this is not correct. For example LC1 sand only occurred in IVCO- 21 and pinch out at the rest of the wells (figure3)

Detailed study of this correlation panel helps in establishing our polygons that defined correct GRV for all the reservoir units (figures4-6).

Pressure data were extrapolated from IVCO-21 well montage to get value for the best technical contact (BTC) for GWC in LC1 unit.

\section{Conclusions}

This evaluation demonstrate that Gazelle discovery do not represent significant volume materiality across LC1, LC2and UC1C reservoirs. The GIIP were summarised in the Table 3, and the lognormal Monte Carlo simulation distributions of GIIP for LC1, LC2 \& UC1C reservoir units are shown in (figures. 7-9).

Geologically, the Gazelle Field comprises a combination stratigraphic/structural trap encompassing Cenomanian-Turonian and Senonian slope channel reservoir sequences deposited within shelf and slope setting. The field is characterised by lateral facies variability as observed from the well correlation panel; which is one of the major geological uncertainty encountered in this field. 


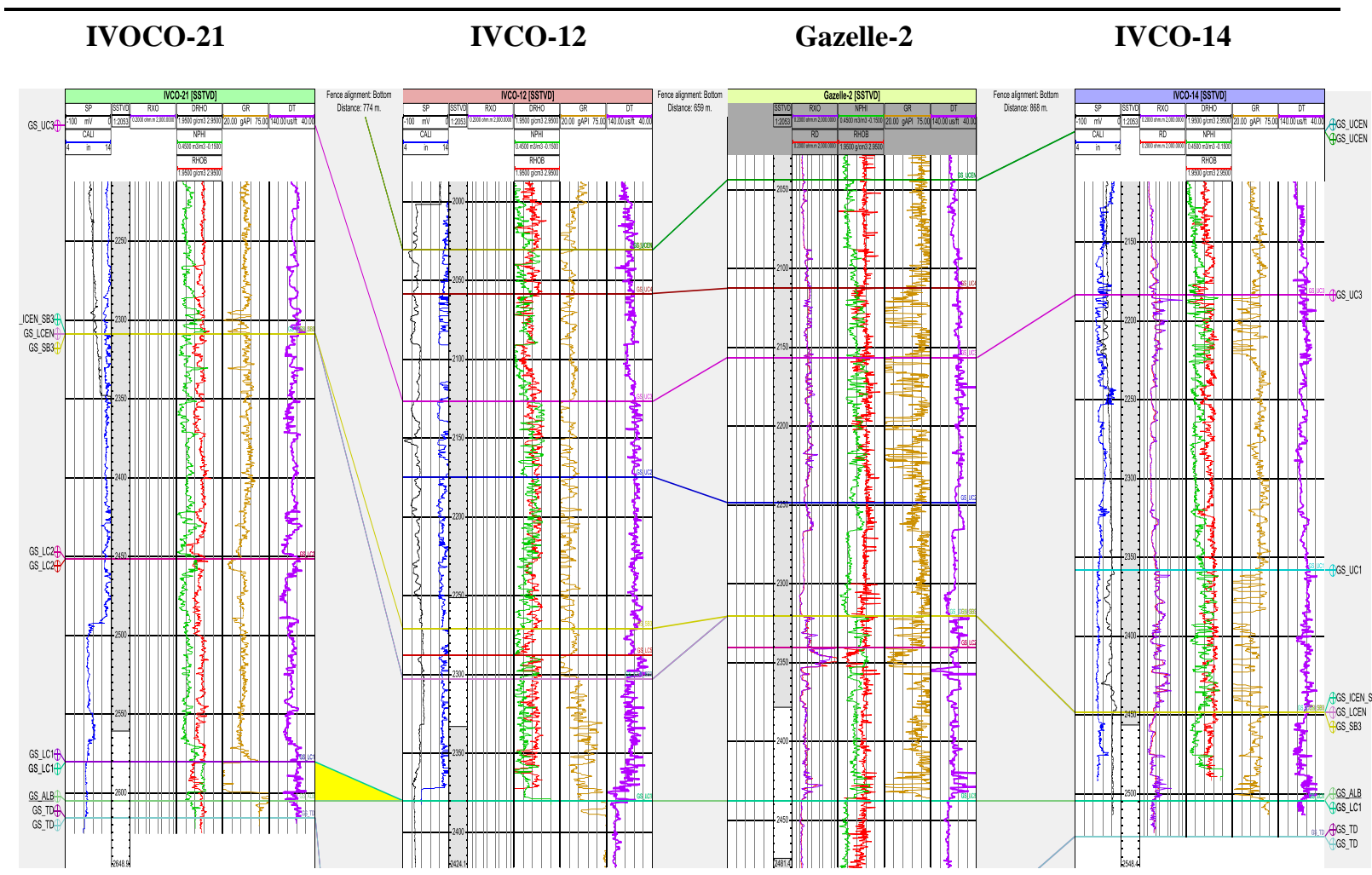

Figure3. Wells Correlation panel for IVCO-21, IVCO-12, Gazelle-2 and IVCO-14 (Top Albian Flattened)

GS_LC1: Top Structure

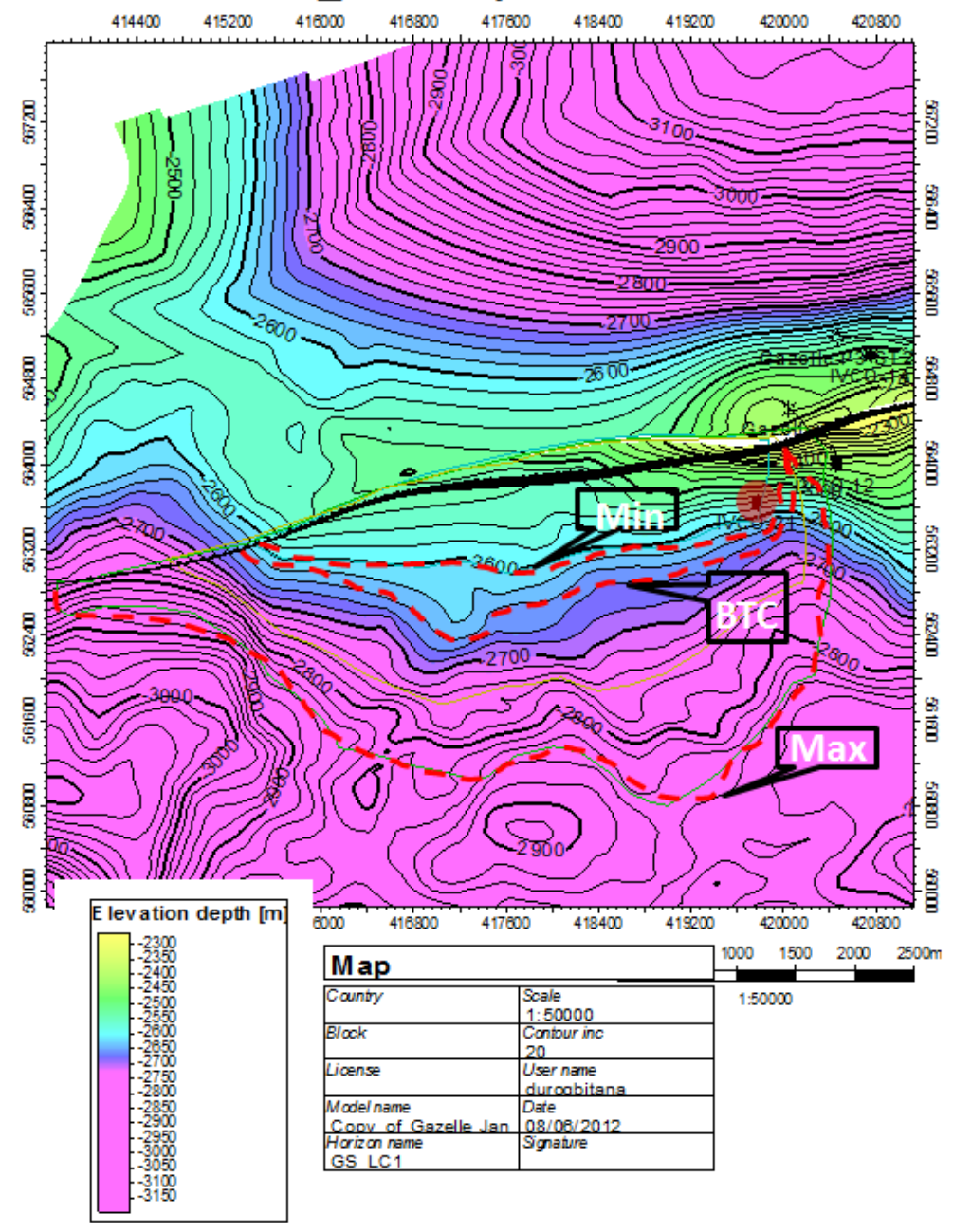

Figure4. Top structure and reservoir unit of LC1 showing Polygons for GRV calculations 


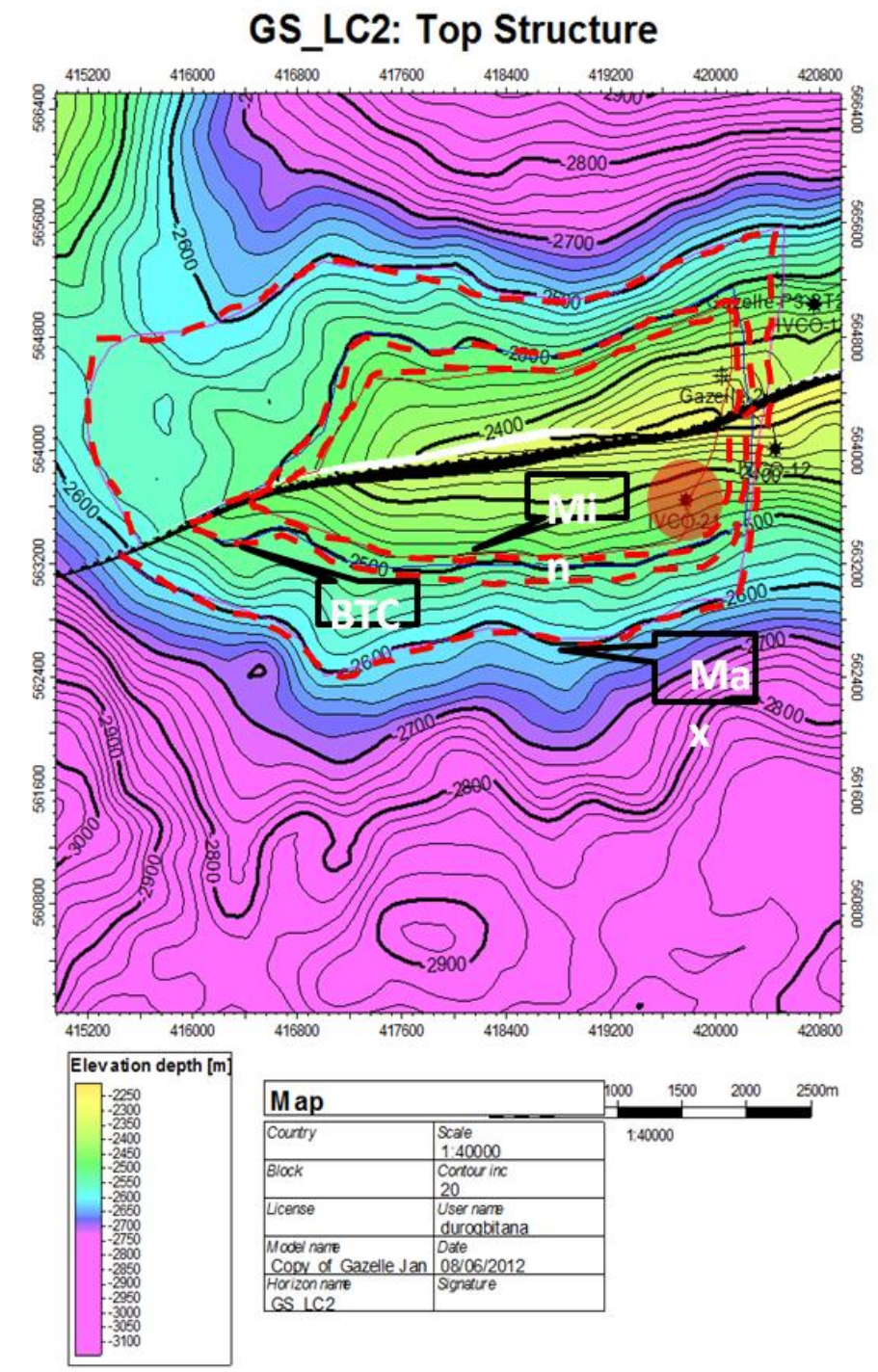

Figure5. Top structure and reservoir unit of LC2 showing Polygons for GRV calculations

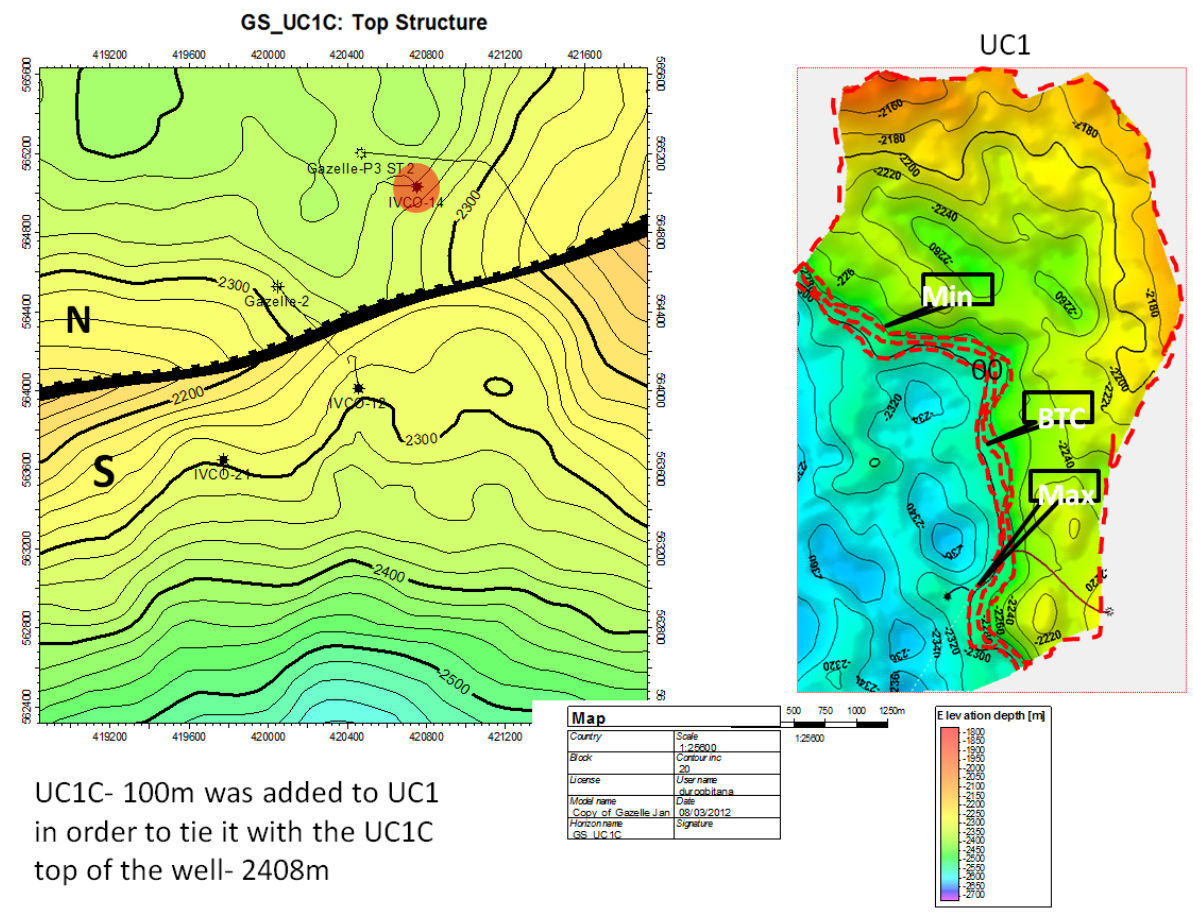

Figure6. Top structure and reservoir unit of UC1C showing Polygons for GRV calculations 
Abimbola Adewole Durogbitan

Table2. Geological Uncertainties

\begin{tabular}{|c|c|c|c|}
\hline \multicolumn{4}{|c|}{ LC1 } \\
\hline $\begin{array}{c}\text { Description of Geological } \\
\text { Uncertainty }\end{array}$ & Low Case & Mid Case & Max Case \\
\hline Depth to Contact & $\begin{array}{l}\text { GDT in IVCO-21 } \\
2602 \mathrm{mTVDSS}\end{array}$ & $\begin{array}{l}\text { Based on the pressure data } \\
\text { interpretation, 2635mTVDSS }\end{array}$ & $\begin{array}{l}\text { Deepest closure } \\
\text { 2900mTVDSS }\end{array}$ \\
\hline Thickness of the Reservoir & $\begin{array}{c}\text { Based on Analogues } 10 \mathrm{~m} \\
\text { net pay }\end{array}$ & Based on well log $12 \mathrm{~m}$ net pay & $\begin{array}{c}\text { Based on Analogues } 18 \mathrm{~m} \\
\text { net pay }\end{array}$ \\
\hline Sand Distribution & $\begin{array}{c}\text { Extent of the sand control } \\
\text { in IVCO-21 }\end{array}$ & Midway & $\begin{array}{l}\text { Extent of lack of sand of } \\
\text { control IVCO-12 }\end{array}$ \\
\hline Area & $3.63 \mathrm{~km} 2$ & $4.55 \mathrm{~km} 2$ & $14.1 \mathrm{~km} 2$ \\
\hline GRV & $36.3 \mathrm{~km} 2 . \mathrm{m}$ & $54.6 \mathrm{~km} 2 . \mathrm{m}$ & $253.8 \mathrm{~km} 2 . \mathrm{m}$ \\
\hline \multicolumn{4}{|c|}{$\mathrm{LC2}$} \\
\hline $\begin{array}{c}\text { Description of Geological } \\
\text { Uncertainty }\end{array}$ & Low Case & Mid Case & Max Case \\
\hline Depth to Contact & $\begin{array}{c}\text { GDT in IVCO-21\& } \\
\text { Gazelle-2 } 2463 \mathrm{mTVDSS}\end{array}$ & $\begin{array}{c}\text { Probably halfway between, } \\
2500 \text { mTVDSS }\end{array}$ & $\begin{array}{l}\text { Deepest closure } \\
2600 \mathrm{mTVDSS}\end{array}$ \\
\hline Thickness of the Reservoir & $\begin{array}{c}\text { Based on Analogues-3m } \\
\text { net pay }\end{array}$ & Based on well log-3.3m net pay & $\begin{array}{c}\text { Based on Analogues- } 4 \mathrm{~m} \\
\text { net pay }\end{array}$ \\
\hline Sand Distribution & $\begin{array}{l}\text { Extent of the sand control } \\
\text { in IVCO-21\& Gazelle-2 }\end{array}$ & Midway & $\begin{array}{c}\text { Extent of lack of sand of } \\
\text { control IVCO-12 \& IVCO- } \\
14\end{array}$ \\
\hline Area & $4.0 \mathrm{~km} 2$ & $5.45 \mathrm{~km} 2$ & $11.89 \mathrm{~km} 2$ \\
\hline GRV & $12.0 \mathrm{~km} 2 . \mathrm{m}$ & $17.99 \mathrm{~km} 2 . \mathrm{m}$ & $47.56 \mathrm{~km} 2 . \mathrm{m}$ \\
\hline \multicolumn{4}{|c|}{ UC1C } \\
\hline $\begin{array}{c}\text { Description of Geological } \\
\text { Uncertainty }\end{array}$ & Low Case & Mid Case & Max Case \\
\hline Depth to Contact & $\begin{array}{l}\text { GDT in IVCO-14 - } \\
\text { 2394mTVDSS }\end{array}$ & $\begin{array}{l}\text { Probably halfway between, } \\
2395 \text { mTVDSS }\end{array}$ & $\begin{array}{c}\text { GOC in Gazelle P3ST2- } \\
\text { 2403mTVDSS }\end{array}$ \\
\hline Thickness of the Reservoir & $\begin{array}{c}\text { Based on Analogues-5m } \\
\text { net pay }\end{array}$ & Based on well log-7m net pay & $\begin{array}{c}\text { Based on Analogues- } 15 \mathrm{~m} \\
\text { net pay }\end{array}$ \\
\hline Sand Distribution & $\begin{array}{c}\text { Extent of the sand control } \\
\text { in IVCO-14 \& Gazelle- } \\
\text { P3ST2 }\end{array}$ & Midway & $\begin{array}{l}\text { Extent of lack of sand of } \\
\text { control IVCO-21 \& } \\
\text { Gazelle-2 }\end{array}$ \\
\hline Area & $3.99 \mathrm{~km} 2$ & $4.16 \mathrm{~km} 2$ & $4.32 \mathrm{~km} 2$ \\
\hline GRV & $19.95 \mathrm{~km} 2 . \mathrm{m}$ & $29.12 \mathrm{~km} 2 . \mathrm{m}$ & $64.84 \mathrm{~km} 2 . \mathrm{m}$ \\
\hline
\end{tabular}

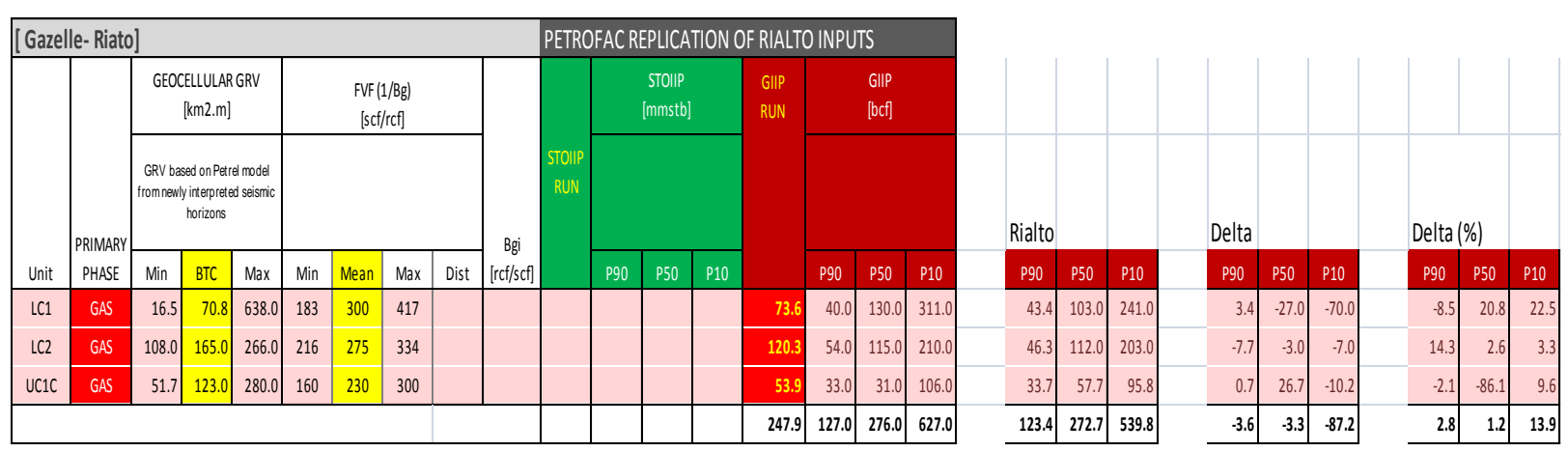

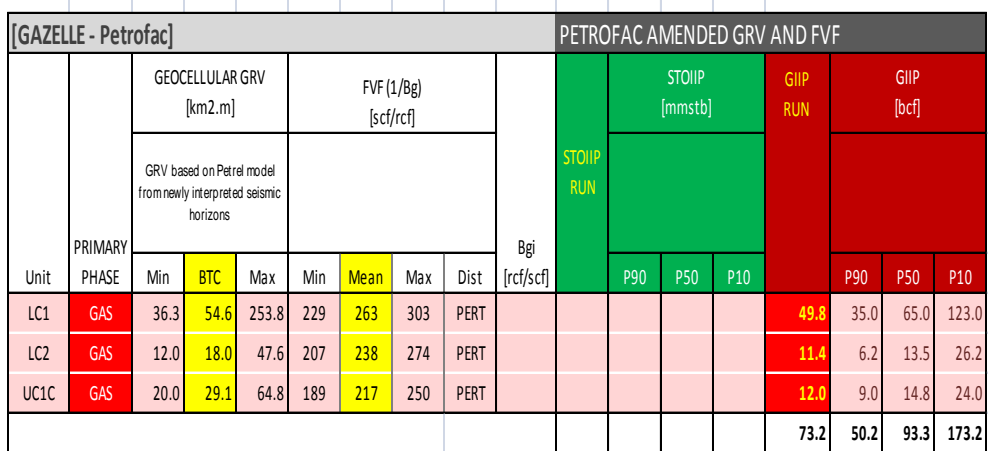

Table3. GIIP Summary Table from Previous (Rialto old) volume, Replication of Rialto- old input volumes and Petrofac-New volumes 
Geological Evaluation and Lateral Facies Variability of gazelle Field: Implication on Volumetric Analysis

Petro physical Parameters- Same for Rialto and Petrofac

\begin{tabular}{|c|c|c|c|c|c|c|c|c|c|c|c|}
\hline \multicolumn{4}{|c|}{$\begin{array}{c}\mathrm{N} / \mathrm{G} \\
{[\mathrm{frac}]}\end{array}$} & \multicolumn{4}{|c|}{$\begin{array}{c}\mathrm{PHI} \\
{[\mathrm{frac}]}\end{array}$} & \multicolumn{4}{|c|}{$\begin{array}{c}\mathrm{Sg} \\
{[\mathrm{frac}]}\end{array}$} \\
\hline \multicolumn{4}{|c|}{ Taken from ranges in $2010 \mathrm{EQ}$ study } & \multicolumn{4}{|c|}{ Taken from ranges in $2010 \mathrm{EQ}$ study } & \multicolumn{4}{|c|}{ Taken from ranges in $2010 \mathrm{EQ}$ study } \\
\hline Min & Mean & Max & Dist & Min & Mean & Max & Dist & Min & Mean & Max & Max \\
\hline 0.53 & 0.83 & 1.00 & & 0.07 & 0.17 & 0.26 & & 0.93 & 0.70 & 0.47 & \\
\hline 0.00 & 0.58 & 1.00 & & 0.06 & 0.19 & 0.31 & & 0.93 & 0.70 & 0.47 & \\
\hline 0.17 & 0.40 & 0.63 & & 0.11 & 0.18 & 0.25 & & 0.87 & 0.75 & 0.63 & \\
\hline
\end{tabular}

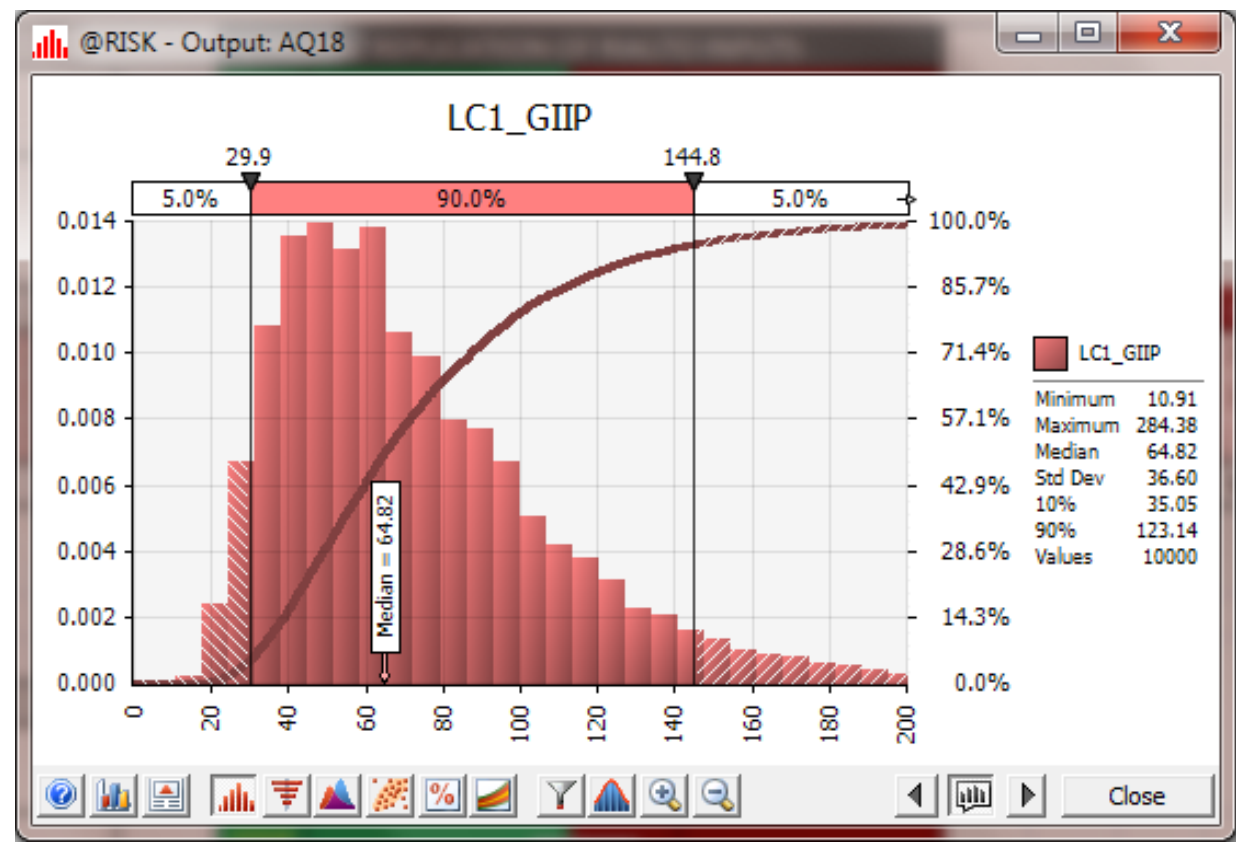

Figure7. Lognormal Monte Carlo simulation result for GIIP in the LC1 reservoir interval (New volumeamended GRV and FVF).

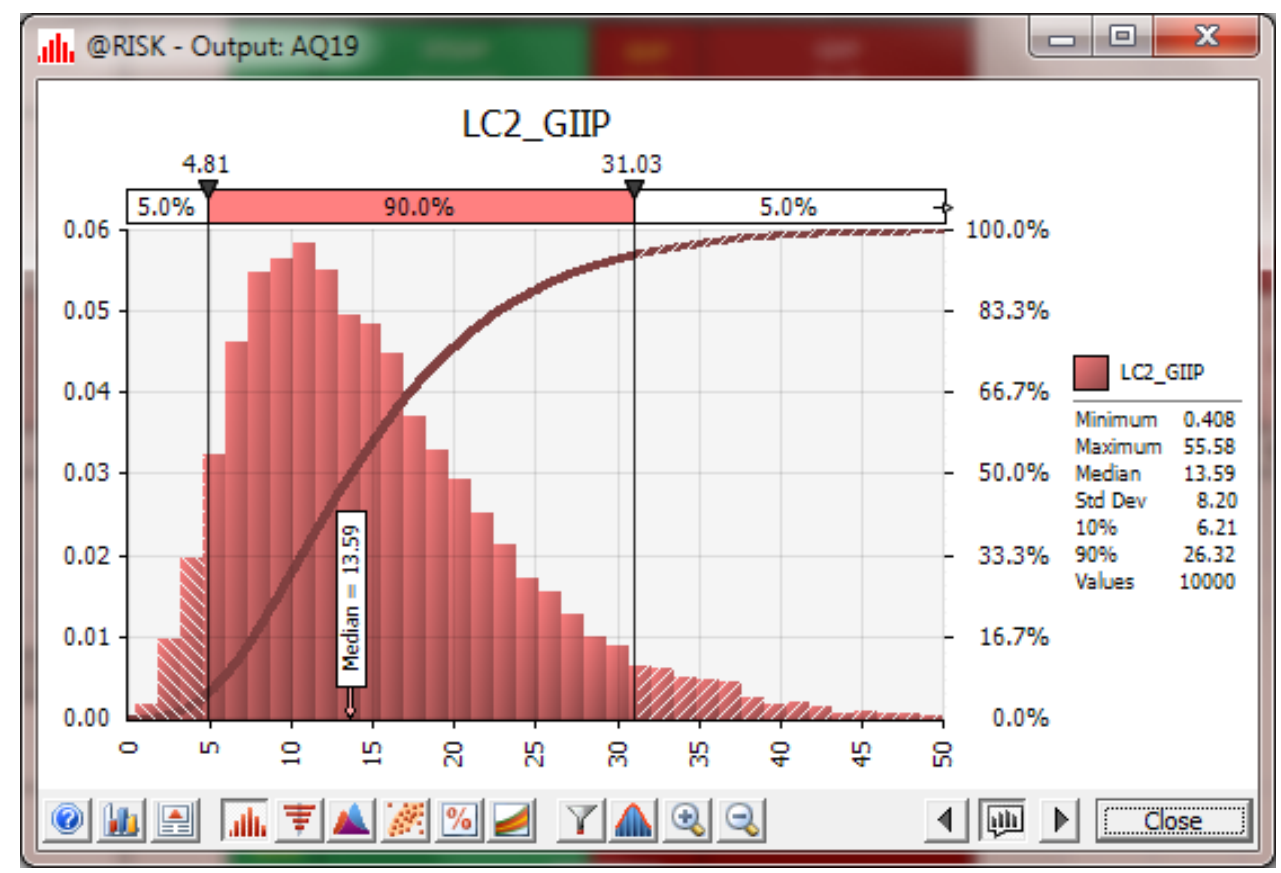

Figure8. Lognormal Monte Carlo simulation result for GIIP in the LC2 reservoir interval (New volumeamended GRV and FVF) 


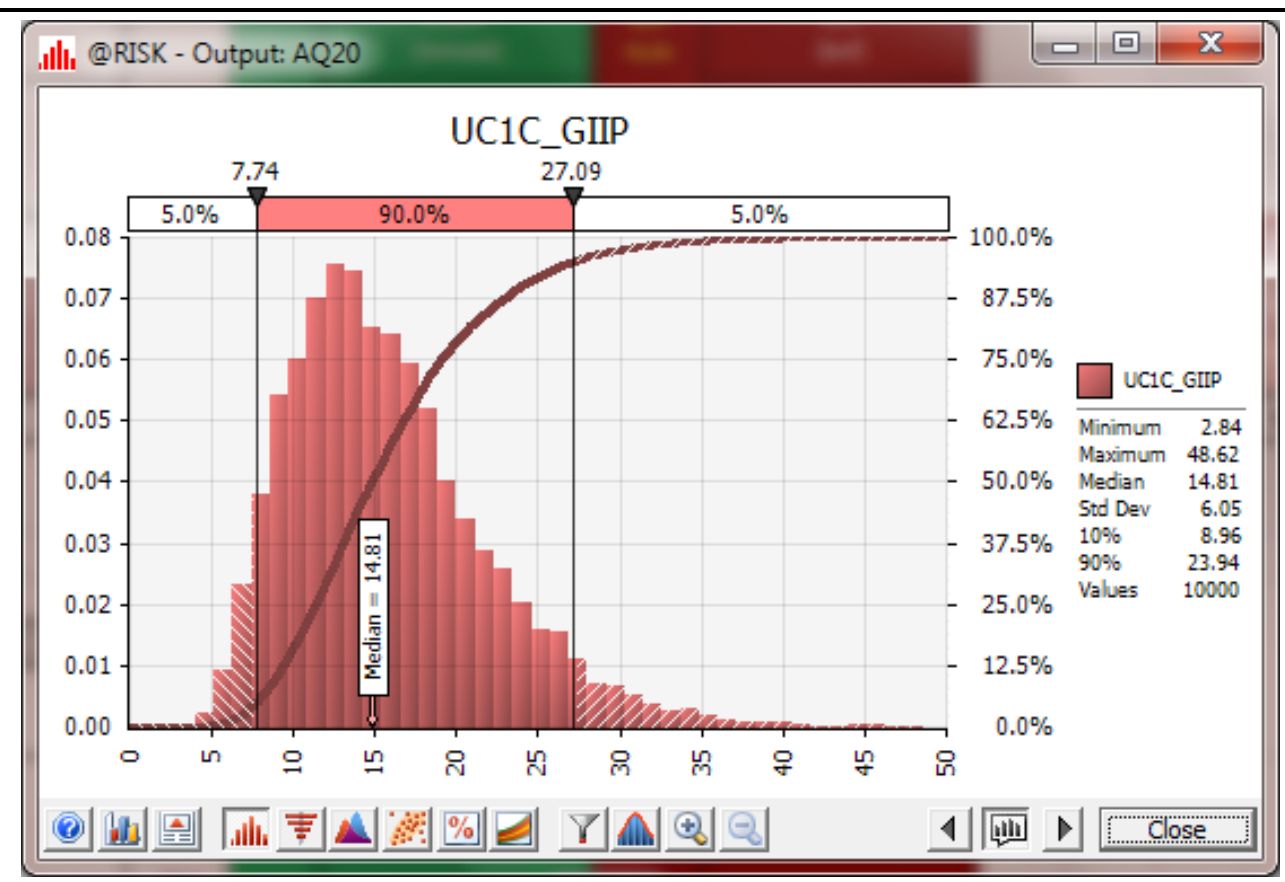

Figure9. Lognormal Monte Carlo simulation result for GIIP in the UClC reservoir interval (New volumeamended GRV and FVF)

\section{REFERENCES}

[1]Morrison J., Boblai V., Tea J., and N'Zalasse B. (1999), a Sequence Stratigraphic approach to Explration and Re-Development in the Abidjan Margin, Côte d'Ivoire. Offshore West Africa 1999, Conference Proceedings, Third Annual Congress, PennWell Publishing.

[2]Gazelle Field Development Plan Rialto 2011- Rialto 